\title{
Evaluation of Water Quality for Drinking and Agricultural Suitability in the Lower Indus Plain in Sindh Province, Pakistan
}

\author{
Asfandyar Shahab ${ }^{1 *}$, Qi Shihua ${ }^{1}$, Audil Rashid ${ }^{2}$, Faizan Ul Hasan ${ }^{3}$, \\ Muhammad Tayyab Sohail ${ }^{4}$ \\ ${ }^{1}$ School of Environmental Studies, China University of Geosciences, \\ Wuhan, Hubei, 430074, People's Republic of China \\ ${ }^{2}$ Department of Environmental Sciences, PMAS Arid Agriculture University Rawalpindi Pakistan \\ ${ }^{3}$ Pakistan Council of Research in Water Resources (PCRWR), Islamabad, Pakistan \\ ${ }^{4}$ School of Public Administration, China University of Geosciences, \\ Wuhan, Hubei, 430074, P. R. China
}

Received: 13 April 2016

Accepted: 20 July 2016

\begin{abstract}
Indus Basin represents a conjunctive system for ground and surface water use. From it, originates the world's largest irrigation system underlain a deep alluvium and well transmissive aquifer resulting in higher water table. At present, this area is at risk of ground water aquifer contamination due to extensive agricultural activities that needs to be constantly monitored. A total of 218 ground water samples were collected across the Sindh Province and were evaluated for drinking and agricultural purpose subjected to Hydrochemical analysis. The analytical parameters were compared with WHO and Pakistan water quality standards and majority of the samples were found not potable. $62.84 \%$ of EC samples, $34.86 \%$ TDS, $43 \%$ $\mathrm{Na}^{+}, 17.88 \% \mathrm{Cl}^{-}, 26.60 \% \mathrm{SO}_{4}^{2-}, 39.44 \% \mathrm{HCO}_{3}^{-}, 41.7 \%$ turbidity and $35.32 \%$ hardness in the samples were found to exceed the WHO standard limit of drinking water. Interpolation technique was used though Arc. GIS to determine the spatial distribution of major ground water quality parameters. Highest concentration was observed mostly at Lower Sindh (Thatta, Badin) where sea water intrusion takes place, Tharparker and central Sindh. Principal Component Analysis and correlation analysis confirms positive association of As with Fe which could be the possible cause of As mobilization in Sindh ground water. The hydrogeochemical facies indicates that alkali $\left(\mathrm{Na}^{+}\right)$exceeds over alkaline earth metals $\left(\mathrm{Ca}^{2+}, \mathrm{Mg}^{2+}\right)$ and $\mathrm{Cl}^{-}$and $\mathrm{HCO}_{3}^{-}$exceeds over $\mathrm{SO}_{4}^{2-}$ indicating saline water and carbonate weathering as the source of solutes in Sindh groundwater. Suitability of groundwater for drinking and agricultural purpose indicates that majority of the samples were very far from drinking water standards while few samples were considered unsuitable for agricultural purpose especially in the lower southern Sindh( Thatta, Badin and Tharparker). Proper drainage
\end{abstract}

\section{Introduction}

*e-mail: asfandyar.shahab@yahoo.com 
practices especially in the irrigated area and lower Sindh Province are recommended in order to reduce the water level and avoid sea water intrusion for better water quality.

Keywords: groundwater quality, Lower Indus Plain, Sindh Province, drinking and irrigation, Arc.GIS

The importance of water for human health, economic development, and population growth can never be overstated. Provision of safe drinking water is a global issue. Groundwater serves an important source of water for drinking, irrigation, industry, and human consumption across the world and is the only renewable source for water in arid regions [1]. Due to its good quality, storage, little seasonal variations and high cleanliness level, humans rely on groundwater more than any other drinking water source. About one third of the world's population is dependent on groundwater (GW) for drinking purposes [2]. This high dependecy has resulted in elevated pressure on available ground water resouces in terms of both quality and quantity. GW quality depends on many factors, including pollutant input derived from agricultural and industrial activities, composition of recharge water, and atmospheric conditions. It is important to examine the quality of ground water prior to its particular use [3]. Water quality problems are more severe in industrialized areas with dense populated and shallow ground water levels.

Heavy metals and organic and inorganic chemicals are found in excess in different parts of the world [4]. Quality of water determines population health [5] so therefore there is a rising concern over water pollution in recent times due to leaching of industrial and agricultural pollutants. A geochemical study of groundwater provides a better insight of possible variations in quality as development progresses. The geochemical information determines the suitability of groundwater for domestic and irrigation purposes.

Groundwater is the major source of drinking water in Pakistan. Groundwater contamination in Pakistan requires significant research resources for the welfare of public health. In Pakistan, about $44 \%$ of the population lack access to safe drinking water and the conditions are much more severe in rural areas [6]. The annual per capita availability of water was $5,800 \mathrm{~m}^{3}$ in 1951 , which decreased to $1,100 \mathrm{~m}^{3}$ in 2006 and is projected to decrease to less than $1,000 \mathrm{~m}^{3}$ in the next decade [7].

Sindh Province constitutes the Lower Indus Plain of Pakistan. The Indus plain aquifer is one of the richest aquifers in terms of groundwater resources. The coast of the Arabian Sea borders southern parts of Sindh Province and the city of Karachi. The water of Sindh is unsuitable for drinking and is most vulnerable to contamination [8] by arsenic. Few studies have been conducted in the province to address various aspects of water quality. Mahmood et al. [9] assessed the seasonal variability in water quality of Lower Sindh Province, while Memon et al. [10] worked on drinking water quality assessment of southern Sindh Province, including Thatta District, Badin, and Tharparker. Majidano et al. [11] and Ali et al. [12] assess water quality in Tando Allah Yar District and Dadu, with special emphasis on arsenic content and its consequences. However, this is the first study to address groundwater quality of the whole province along with the spatial distribution of water quality parameters. The present study was designed to determine the spatial distribution and relationship among various water quality parameters in Indus plain aquifer of Sindh Province. Effort was also made to analyze the water quality suitability for drinking and irrigation purposes. We assume the findings of this study will enhance the understanding of Hydrochemical system of lower Indus plain and identification of the possible sources of groundwater contamination in Sindh Province of Pakistan to be successively used as a valuable tool for effective management of drinking water resource.

\section{Study Area}

Sindh, in southeastern Pakistan, is one the four provinces that constitute the Lower Indus Plain. It stretches from $66^{\circ} 8^{\prime}$ East Longitude to $71^{\circ}$ and lies between $24^{\circ} 4^{\prime} \mathrm{N}$ to $28^{\circ} 7^{\prime} \mathrm{N}$ and covers about 46,569 miles $^{2}$. Groundwater's natural equilibrium was disturbed with the onset of a canal irrigation system in the Indus Basin in the middle of the $19^{\text {th }}$ century, consequently posing a challenge in the management of this aquifer and related environmental issues [13]. The area is mostly affected with water logging and salinity, especially in Sindh's irrigated area. The mean temperature is $35^{\circ} \mathrm{C}$ in summer months and $16^{\circ} \mathrm{C}$ in winter. Occasionally the temperature rises to $50^{\circ} \mathrm{C}$ in summer. The average annual rainfall is only 6-7 in. Rainfall scarcity is compensated by Indus River inundation twice a year, caused by rainfall in monsoon season and snowmelt from the Himalayas. Rice is the most important crop cultivated here and is grown within the delta plains of Sindh and in annually inundated lands.

\section{Geology and Hydrogeology}

The study area is mostly covered by sedimentary rocks. The geology of the Sindh Plain mainly is composed of Cretaceous and Tertiary formations, which are composed of limestone, dolomite, marl, chert, marly limestone, and chalky limestone with chert interaction [14]. The geology of Sindh is divided into three main regions: the mountain ranges of Kirthar, Pab containing a chain of minor hills in the west, and in the east it is covered by the Thar Desert. In the north, Sindh includes rocks of the Laki Range extending to the Suleiman Range, and its southernmost part is encircled by the Arabian Sea. The sub-surface rocks are about 20,000 feet thick and belong to the Cretaceous 


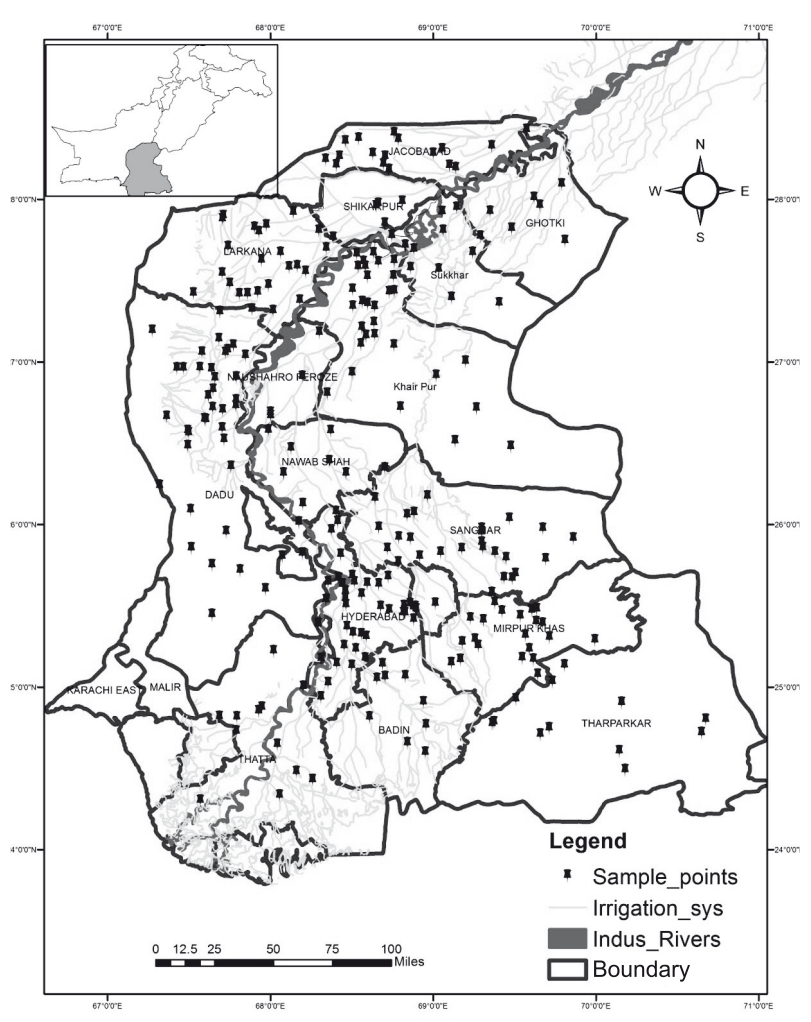

Fig. 1. Map of Sindh Province, Pakistan with study locations.

and Pre-Cretaceous periods. Mostly the rocks are of sedimentary origin of clastic and non-clastic nature and belong to marine, partly marine, and fluvial depositional environments. The lower Indus aquifer is a rich water resource. Most of the fresh water lies up to $50 \mathrm{~m}$ deep, and beneath the water it becomes saline. The rich irrigation system mainly from the Indus River (Fig. 1) is the main source of recharge. Mostly shallow groundwater prevails in all of Sindh, especially in the irrigated areas, and can be considered water-logged due to the intensive irrigation system.

\section{Materials and Methods}

\section{Sample Collection and Analysis}

In order to assess the groundwater quality, 218 groundwater samples were collected across the whole of Sindh Province and analyzed for physicochemical analysis in the water quality laboratory of the Pakistan Council of Research in Water Resources (PCRWR). The groundwater samples were collected randomly from wells, bore holes, and hand pump by adopting standard protocol. All the samples were analyzed for electrical conductivity (EC), $\mathrm{pH}$, and total dissolved solids (TDS); and major cations like calcium, magnesium, sodium, potassium, and anions including bicarbonate, carbonate, chloride, nitrate, and sulphate - adopting the standard methods of the American Public Health Association APHA [15]. All the results were evaluated in accordance with the drinking water quality standards specified by the World Health Organization (WHO) [16]. The analysis of water samples were carried out in laboratory, by adopting standard analytical techniques. Arsenic was measured in the PCRWR laboratory using a Merck Arsenic Kit for 0.01-0.5 mg/L. Environmental hazards related to the rising water table were monitored through observation wells installed in the irrigated area of Sindh.

\section{Statistical Analysis of Data}

Mean values and standard deviations were calculated using descriptive statistics, whereas Pearson correlation analysis was performed to identify the relationships among water quality parameters. The degree of intercorrelation among soil variables and relevant significance of individual parameter were evaluated by extracting Principal Component Analysis based information. All analyses were performed in SPSS release 16 for Windows $\AA$. ArcGis 10.1 was used to determine spatial distribution of basic water quality parameters through the interpolation technique by using the following formula [17].

$$
\hat{Z}=\sum_{i=1}^{n} \lambda \mathrm{iZ}(\mathrm{si})
$$

...where $\hat{Z}$ is to be estimated, $\mathrm{n}$ is the number of sample points used for prediction, and $\mathrm{Z}(\mathrm{si})$ is the observed value of location si.

We used Aqua Chem 2010.1 to develop hydrological facies though piper plot to depict dominant water type, and a Wilcox diagram was used to determine the suitability of groundwater for irrigation. EC and Sodium Adsorption Ratio (SAR) were used to determine the groundwater suitability for irrigation purposes in the study area.

\section{Results and Discussion}

\section{Groundwater Chemistry and Spatial Distribution}

Groundwater samples analyzed for physical and chemical parameters were compared with drinking water quality standards of the Pakistan Standards and Quality Control Authority (PSQCA) and WHO [18] (Table 1). EC value ranged from 249 to $15,720 \mu \mathrm{S} / \mathrm{cm}$, with a mean value of $2281.33 \mu \mathrm{S} / \mathrm{cm}$, which is significantly higher than the standard limit. High EC values are observed at District Tharparker (Fig. 4a), Badin, parts of Dadu, the Nausheroferoz and Khairpur districts, and is due to the distribution of naturally occurring minerals in earth [9]. The hazardous range of EC values is due to seawater intrusion by the Arabian Sea in lower Sindh, the high water table, and the waterlogged conditions that prevail in the whole irrigated area of the province.

Neutral to slightly alkaline $\mathrm{pH}$ prevails in the GW of Sindh Province. Slightly acidic to neutral $\mathrm{pH}$ in the lower 
Table 1. Summary of statistics and groundwater comparison using Pakistan Standards and Quality Control Authority (PSQCA) and World Health Organization (WHO) standards.

\begin{tabular}{|c|c|c|c|c|c|c|c|}
\hline Parameters & $\begin{array}{l}\text { PSQCA } \\
\text { standards }\end{array}$ & $\begin{array}{l}\text { WHO } \\
\text { standards }\end{array}$ & Range & Mean & $\begin{array}{l}\text { No. of samples } \\
\text { exceeding WHO } \\
\text { standards }\end{array}$ & $\begin{array}{l}\% \text { of Sample } \\
\text { exceeding WHO } \\
\text { standards }\end{array}$ & Undesirable effects \\
\hline $\mathrm{pH}$ & $6.5-8.5$ & $6.5-8.5$ & $6.5-8.8$ & 7.47 & 6 & 2.75 & Taste \\
\hline $\mathrm{EC}$ & & 1000 & $249-15720$ & 2281.33 & 137 & 62.84 & \\
\hline TDS & 1500 & 1000 & $159-10061$ & 1405.72 & 76 & 34.86 & $\begin{array}{l}\text { Gastrointestinal } \\
\text { irritation }\end{array}$ \\
\hline $\mathrm{Na}$ & & 200 & $9-2940$ & 268.20 & 94 & 43 & \\
\hline K & & & & 5.64 & & & Bitter taste \\
\hline $\mathrm{Mg}$ & 150 & 150 & $5-400$ & 66.89 & 18 & 8.2 & \\
\hline $\mathrm{Ca}$ & 200 & 200 & $14-380$ & 92.67 & 21 & 9.6 & Scale formation \\
\hline $\mathrm{Fe}$ & 1 & 0.3 & $0-1$ & 0.11 & 21 & 9.6 & \\
\hline $\mathrm{F}$ & 1.5 & 1.5 & $0-7.60$ & 0.78 & 33 & 15.13 & Flourosis \\
\hline $\mathrm{Cl}$ & 600 & 600 & $2-4114$ & 382.04 & 39 & 17.88 & Salty taste \\
\hline $\mathrm{SO}_{4}$ & 400 & 400 & $0.60-2006$ & 286.22 & 58 & 26.60 & Laxative effect \\
\hline $\mathrm{HCO}_{3}$ & & 350 & $30-1500$ & 351.41 & 86 & 39.44 & Nausea / irritability \\
\hline $\mathrm{NO}_{3}(\mathrm{~N})$ & 10 & 10 & $0-25$ & 0.96 & 1 & 0.4 & Blue baby skin \\
\hline As & 50 & 10 & $0-250$ & 22.77 & 52 & 23.85 & $\begin{array}{l}\text { Skin pigmentation / } \\
\text { cancer }\end{array}$ \\
\hline Turbidity & 25 & 5 & $0-665$ & 17.75 & 91 & 41.7 & $\begin{array}{l}\text { Gastrointestinal } \\
\text { illness }\end{array}$ \\
\hline Hardness & & 300 & $75-2500$ & 496.47 & 123 & 56.42 & Dietary problems \\
\hline Alkalinity & & & $0.40-30$ & 6.95 & & & \\
\hline
\end{tabular}

All units are in $\mathrm{mg} / \mathrm{l}$ except $\mathrm{pH}, \mathrm{EC}(\mu \mathrm{S} / \mathrm{cm})$, arsenic $(\mathrm{ppb})$, turbidity (NTU), alkalinity (mmol/l)

part of Dadu and Larkana districts, and a slightly alkaline pH was observed in Tharparker, Ghotki, Sukkur, Khairpur, Nawabshah, and Mirpurkhas districts (Fig. 3b). Increases in $\mathrm{pH}$, alkalinity, and hardness may be a mitigating factor in corrosion [19]. TDS value ranged from 159 to $10,061 \mathrm{mg} / \mathrm{l}$ with a mean value of $1,405 \mathrm{mg} / \mathrm{l}$ (Table 1). Excessive concentrations of TDS were observed in Tharpaker and parts of Sanghar, Mirpurkhas, and Nausherferoz districts (Fig. 3c). The TDS concentrations of GW samples were mainly comprised of bicarbonates, carbonates, sulphates, chlorides, and calcium contribute that are attributed primarily due to geological characteristics of the Sindh Province and may originate from natural sources, sewage, urban runoff, and industrial wastewater [20].

The presence of two important ions, $\mathrm{Ca}^{2+}$ and $\mathrm{Mg}^{2+}$, contribute to hardness, which is present mainly in sedimentary rocks (limestone, dolomite, shale). The geology of the Lower Indus Basin is mainly composed of limestone, dolomite, and a lesser amount of Eoceneage salt evaporate [21]. The groundwater contents of $\mathrm{Ca}^{2+}$ and $\mathrm{Mg}^{2+}$ ions range from $14-380 \mathrm{mg} / \mathrm{L}$ and 5 to 400 mg/l (Table 1). Apart from Ghotki, Sukkur, Kashmore, Larkana, and Tando AllahYar districts having concentrations within maximum allowable limits, all other areas exhibit much higher concentrations (Fig. 3d). In cultivated areas where lime and fertilizers are used, excessive hardness may also be due to other chemicals such as nitrates [22]. Hard water can form scum and curd on boiling, discolor fabrics, and lead to medical problems such as excessive gas, kidney stones, diarrhea, and heart problems [23].

Sodium and chloride concentrations vary from 9 to $2,940 \mathrm{mg} / \mathrm{l}$ and 2 to $4,114 \mathrm{mg} / \mathrm{l}$ with an average of 268.20 and $382.04 \mathrm{mg} / \mathrm{l}$, respectively (Table 1). Both $\mathrm{Na}^{+}$and $\mathrm{Cl}^{-}$ are in excess in Sindh and exceed by $43 \%$ and $17.88 \%$ the guideline set by WHO for drinking water, and both exhibit mainly similar patterns of distribution (Figs 3e, f), which makes the water saline in nature. Tharparker and Badin districts and a few other patches in the province were found to be affected with hazardous concentrations of $\mathrm{Na}^{+}$and $\mathrm{Cl}^{-}$, while parts of Dadu, Khairpur, Sukkur, and Nausheroferoz were affected by higher concentrations than the standards. Tharparker is mostly a desert area while Badin and Thatta adjoin the Arabian Sea, where seawater intrudes, resulting in waterlogging and salinity that reflect the higher values of both $\mathrm{Na}^{+}$and $\mathrm{Cl}^{-}$. Morever, intensive agricultural activities, use of 
agrochemicals in southern Sindh (Thatta, Badin, and Thar), waterlogging, and salinity affect the whole irrigated area of Sindh (Steenbergen et al. [24]), and dumping of urban and industrial wastes deteriorate drinking water quality [9].

Bicarbonate and sulphate concentrations ranged from 75 to $2,500 \mathrm{mg} / \mathrm{l}$ and 0.60 to $2,006 \mathrm{mg} / \mathrm{l}$ with mean values of 351.41 and 286.22, respectively (Table 1). The districts of Ghotki, Sukkur, Thatta, parts of Sanghar, Hyderabad, and Dadu are under acceptable concentrations of $\mathrm{SO}_{4}^{2-}$, while the concentration exceeds the maximum allowable limit in areas like Tharparker, Badin, Mityari, Jacobabad, and parts of Khairpur (Fig. 3g). Bicarbonate also shows a mostly similar pattern of distribution (Fig. 3h). Sanghar, MirpurKhas, and Kashmore near Jacobabad and parts of Hyderabad have bicarbonate concentrations within the standard range, while a hazardous concentration was observed in Tharparker, Badin, and parts of Nawabshah, Shikarpur, and Larkana. Excessive use of fertilizers and geology play an important role in their distribution. Gypsum and anhydrite are found in Sindh Province, which results from the dissolution of minerals such anhydrite, gypsum, and limestone, along with an absence of usable groundwater in the delta region of Thatta, Badin, and south of Hyderabad due to seawater intrusion [23].

Arsenic is the most widespread heavy metal in Sindh, and in some areas contamination exceeds $200 \mu \mathrm{g} / \mathrm{L}$ PCRWR [25]. Previous studies on As distribution in groundwater in districts of Sindh showed elevated concentrations of As (10-600 $\mu \mathrm{g} / \mathrm{L})$, exceeding the WHO limit in groundwater of Khairpur, Thatta, Matiari, Tando, Mohammad, and Khan districts, and other parts of Sindh [26-28]. In the present study, the detected arsenic concentration ranges from $0-250 \mathrm{ppb}$ with the mean value of $22.77 \mathrm{ppb}$ (Table 1). Parts of Larkana, Khairpur, Sanghar and Mirpur Khas are within the acceptable range of As, while parts of Hyderabad, Mityari, Dadu, Ghotki, Tharparker, and Jacobabad are affected by higher concentrations (Fig. 3i). Long-term exposure to higher concentrations of arsenic can cause health problems concerning skin pigmentation and cancer [29]. The distribution of As throughout the Indus Plain aquifer is from geogenic sources and mainly due to moderately saline, slightly alkaline, and anox conditions, along with higher concentrations of $\mathrm{Fe}$ in the groundwater [30]. According to water Pakistan quality survey report, the availability of safe drinking water in Sindh is very poor and the consumers are directly exposed to the GW contamination PCRWR [31]. Since GW is the main source in Sindh Province for provision of drinking water, the facts highlighted in the present study manifests that awareness about the significance of safe drinking water and hazards of the unsafe drinking water is entirely negligible among the general public. An urgent intervention both at public awareness and policy level is needed to curtail further deterioration of GW in Sindh province. Lack of public health education and community motivation renders the people more prone to arsenic especially in Central and Southern Sindh [10, 32].

\section{Relationship and Behavior of Major Ions}

A realistic relationship between two parameters for water quality description can be described by mathematical models. This analysis provides a mechanism for forecasting and provides a means to establish the nature of the relationship between the variables. Pearson's

Table 2. Pearson's correlation between physicochemical parameters.

\begin{tabular}{|c|c|c|c|c|c|c|c|c|c|c|c|c|c|c|}
\hline & $\mathrm{pH}$ & $\mathrm{Cond}$ & $\mathrm{TDS}$ & $\mathrm{Na}$ & $\mathrm{K}$ & $\mathrm{Mg}$ & $\mathrm{Ca}$ & $\mathrm{Fe}$ & $\mathrm{F}$ & $\mathrm{Cl}$ & $\mathrm{SO}_{4}$ & $\mathrm{HCO}_{3}$ & $\mathrm{NO}_{3}$ & $\mathrm{As}$ \\
\hline $\mathrm{pH}$ & 1.00 & & & & & & & & & & & & \\
\hline $\mathrm{Cond}$ & -0.08 & 1.00 & & & & & & & & & & & \\
\hline $\mathrm{TDS}$ & -0.11 & $\mathbf{0 . 9 7}$ & 1.00 & & & & & & & & & & & \\
\hline $\mathrm{Na}$ & -0.11 & $\mathbf{0 . 8 9}$ & $\mathbf{0 . 9 3}$ & 1.00 & & & & & & & & & & \\
\hline $\mathrm{K}$ & -0.04 & 0.27 & 0.09 & 0.07 & 1.00 & & & & & & & & & \\
\hline $\mathrm{Mg}$ & -0.20 & $\mathbf{0 . 7 3}$ & $\mathbf{0 . 7 3}$ & $\mathbf{0 . 6 4}$ & 0.13 & 1.00 & & & & & & & & \\
\hline $\mathrm{Ca}$ & -0.16 & $\mathbf{0 . 7 9}$ & $\mathbf{0 . 8 1}$ & $\mathbf{0 . 6 9}$ & 0.13 & $\mathbf{0 . 7 7}$ & 1.00 & & & & & & & \\
\hline $\mathrm{Fe}$ & -0.12 & 0.24 & 0.22 & 0.20 & 0.15 & 0.32 & 0.23 & 1.00 & & & & & & \\
\hline $\mathrm{F}$ & 0.05 & 0.49 & 0.49 & 0.40 & 0.11 & 0.42 & 0.26 & 0.25 & 1.00 & & & & & \\
\hline $\mathrm{Cl}$ & -0.02 & $\mathbf{0 . 7 3}$ & $\mathbf{0 . 7 6}$ & $\mathbf{0 . 7 3}$ & 0.08 & $\mathbf{0 . 6 2}$ & $\mathbf{0 . 5 4}$ & 0.18 & $\mathbf{0 . 7 3}$ & 1.00 & & & & \\
\hline $\mathrm{SO} 4$ & -0.10 & $\mathbf{0 . 7 6}$ & $\mathbf{0 . 7 7}$ & $\mathbf{0 . 6 9}$ & 0.05 & $\mathbf{0 . 7 7}$ & $\mathbf{0 . 6 7}$ & 0.23 & $\mathbf{0 . 5 7}$ & $\mathbf{0 . 7 2}$ & 1.00 & & & \\
\hline $\mathrm{HCO} 3$ & -0.25 & $\mathbf{0 . 7 0}$ & $\mathbf{0 . 7 2}$ & $\mathbf{0 . 6 6}$ & 0.10 & $\mathbf{0 . 7 2}$ & $\mathbf{0 . 7 6}$ & 0.33 & 0.43 & 0.53 & $\mathbf{0 . 6 3}$ & 1.00 & & \\
\hline $\mathrm{NO} 3$ & -0.09 & 0.31 & 0.31 & 0.29 & 0.02 & 0.30 & 0.29 & 0.01 & 0.03 & 0.24 & 0.19 & 0.20 & 1.00 & \\
\hline $\mathrm{As}$ & -0.01 & 0.22 & 0.22 & 0.18 & 0.07 & 0.33 & 0.30 & $\mathbf{0 . 6 2}$ & 0.13 & 0.16 & 0.22 & 0.33 & 0.06 & 1.00 \\
\hline
\end{tabular}



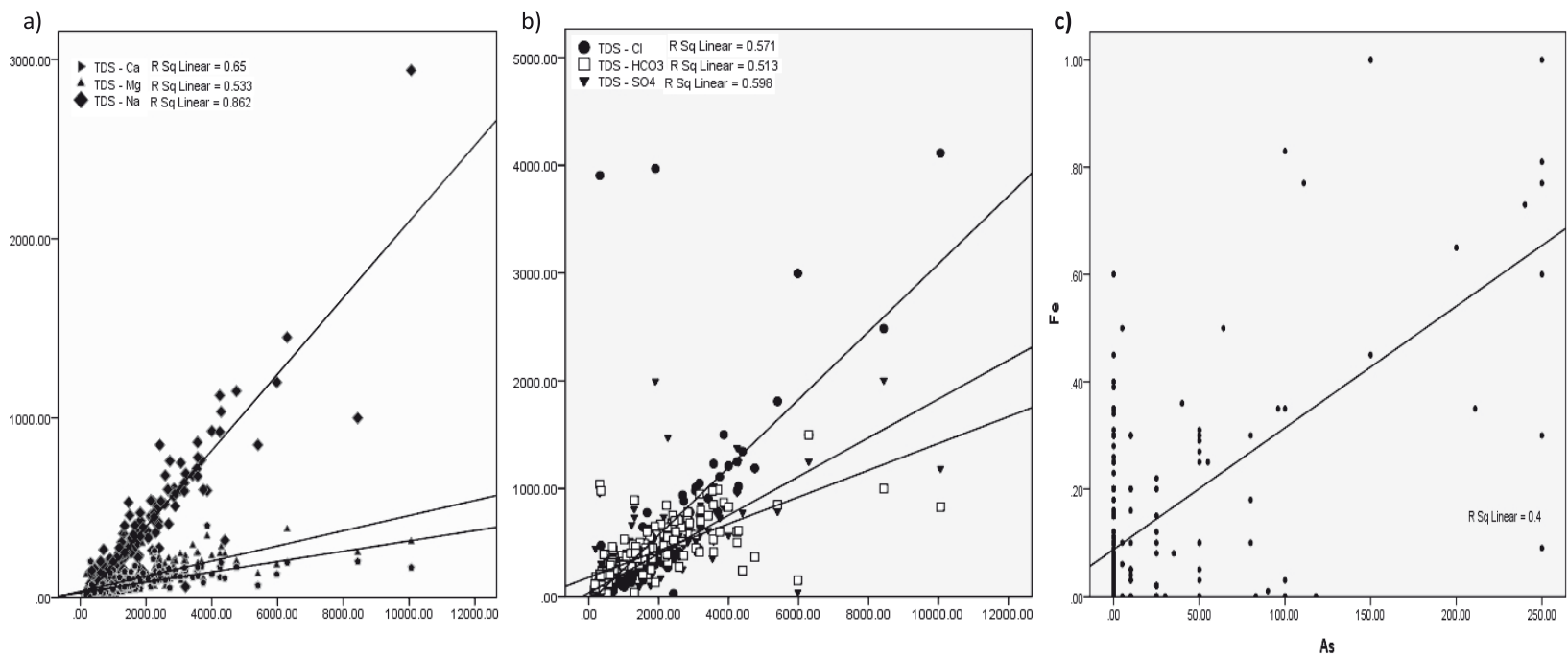

Fig. 2. Correlation analysis: a) Relationship of TDS with cations, b) anions, c) As with Fe.

correlation analysis was performed for multivariate parameters (Table 2). A strong positive correlation exists among EC and TDS and exhibits good positive correlation with $\mathrm{Na}^{+}, \mathrm{Ca}^{2+}, \mathrm{Mg}^{2+}, \mathrm{Cl}^{-}, \mathrm{SO}_{4}^{2-}$, and $\mathrm{HCO}_{3}^{-} \cdot \mathrm{Ca}^{+2}-\mathrm{Cl}^{-}$, $\mathrm{Mg}^{+2}-\mathrm{Cl}^{-}, \mathrm{Mg}^{+2}-\mathrm{SO}_{4}^{2-}-\mathrm{HCO}_{3}^{-}, \mathrm{CO}_{3}^{-}$, and $\mathrm{Na}^{+}-\mathrm{Cl}^{-}$are also the more significant correlation pairs. TDS is a sum of all the cations and anions in water. The relationship of TDS

Table 3. PCA results using varimax rotation with Kaiser normalization.

\begin{tabular}{|c|c|c|c|}
\hline \multicolumn{4}{|c|}{ Rotated Component Matrix ${ }^{\mathrm{a}}$} \\
\hline parameters & PC1 & $\mathrm{PC} 2$ & $\mathrm{PC} 3$ \\
\hline $\mathrm{pH}$ & -.030 & -.124 & -.683 \\
\hline $\mathrm{EC}$ & .921 & .156 & .129 \\
\hline TDS & .939 & .113 & .153 \\
\hline $\mathrm{Na}$ & .880 & .071 & .152 \\
\hline K & .098 & .246 & .005 \\
\hline $\mathrm{Mg}$ & .770 & .317 & .248 \\
\hline $\mathrm{Ca}$ & .765 & .233 & .365 \\
\hline $\mathrm{Fe}$ & .111 & .882 & -.014 \\
\hline $\mathrm{F}$ & .647 & .172 & -.504 \\
\hline $\mathrm{Cl}$ & .869 & .071 & -.210 \\
\hline $\mathrm{SO}_{4}$ & .854 & .163 & -.011 \\
\hline $\mathrm{HCO}_{3}$ & .717 & .350 & .266 \\
\hline $\mathrm{NO}_{3}$ & .316 & -.119 & .489 \\
\hline As & .098 & .854 & .033 \\
\hline variance $\%$ & 44.50 & 14.13 & 9.52 \\
\hline Eigenvalues & 6.751 & 1.531 & 1.11 \\
\hline
\end{tabular}

Bold values indicate highest significant factor loadings between variables within principal components with cations (Fig. 2a) shows a strong positive correlation with $\mathrm{Na}^{+}, \mathrm{Ca}^{2+}$, and $\mathrm{Mg}^{2+}$ with $\mathrm{R}^{2}$ value of $0.862,0.66$, and 0.533 , respectively. Also, a good positive correlation exists between TDS and anions, including $\mathrm{Cl}^{-}, \mathrm{HCO}_{3}^{-}$, and $\mathrm{SO}_{4}^{2-}$ with $0.571,0.513$, and $0.598 \mathrm{R}^{2}$ value (Fig. $2 \mathrm{~b}$ ).

The result illustrates that As shows a positive relationship with $\mathrm{Fe}\left(\mathrm{R}^{2}=0.4\right)$ (Fig. 2c) and from Pearson's correlation (0.62) (Table 2). This suggests that Fe could be the cause of As release in groundwater.

\section{Principal Component Analysis}

In order to know the association among the components in Sindh groundwater, PCA was performed and the results are given in Table 3. Three major components (PC1, PC2, and PC3) were realized in the samples, which explained $68.1 \%$ of the total variance in the dataset. PC1 has high loadings of $\mathrm{Na}^{+}, \mathrm{Mg}^{2+}, \mathrm{Ca}^{2+}$, $\mathrm{Cl}^{-}, \mathrm{SO}_{4}^{2-}, \mathrm{HCO}_{3}^{-}, \mathrm{EC}$, and TDS, accounting for $45.1 \%$ of the total variance. The result is in accordance with the findings of Abbas et al. [33] and Helena et al. [34]. The results of PC1 explain the positive relationship among cations and anions and their contributions to EC and TDS. Moreover, high concentrations of $\mathrm{HCO}_{3}^{-}, \mathrm{SO}_{4}{ }^{2-}$, and $\mathrm{Cl}^{-}$is a major contributor to the mineralization of groundwater as confirmed by the positive loadings with TDS (PC1). Mobilization of $\mathrm{As}$ is positively affected by $\mathrm{Fe}$ in groundwater as PC2 shows significant positive loadings for As and Fe. As mobilization in Sindh groundwater could be through reductive dissolution of FEOOH in the alluvial aquifer of Sindh under reducing conditions [35]. High As concentrations are also concomitant to higher concentrations of bicarbonate in the groundwater. Bicarbonate likely acts as a major arsenic leaching agent [36]. Bicarbonate ions may create a complex with FEOOH, replacing As from the surface of the sediments and minerals, leading to arsenic release in the groundwater [37]. In the present study, arsenic and bicarbonate show a positive correlation $(\mathrm{r}=0.33)$ (Table 2), which 
a)

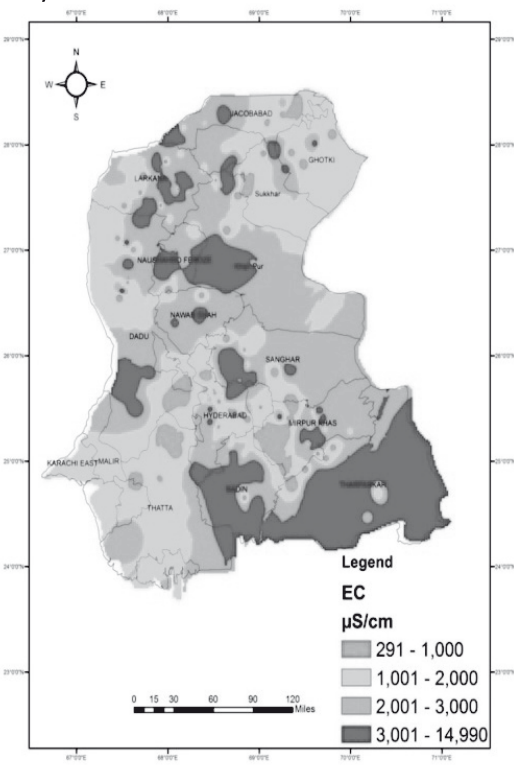

d)

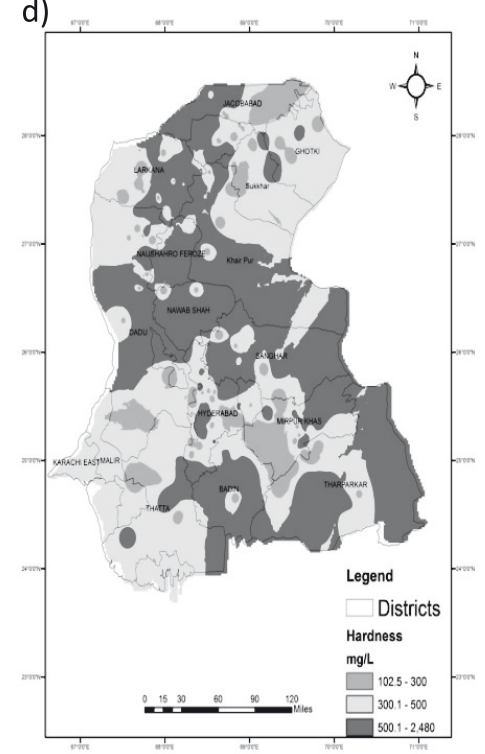

g)

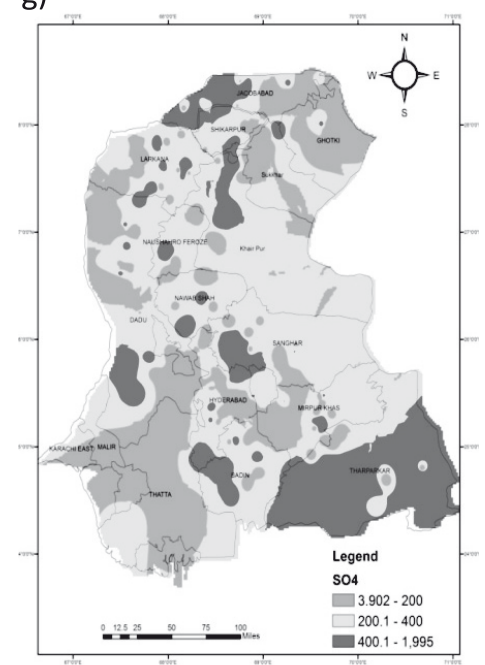

b)

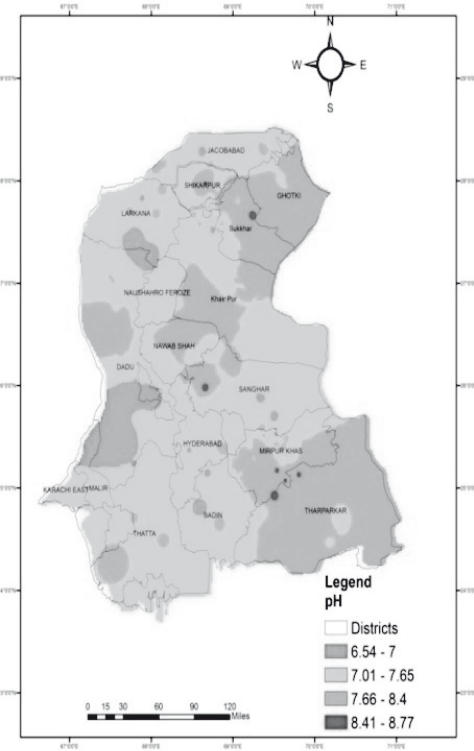

e)

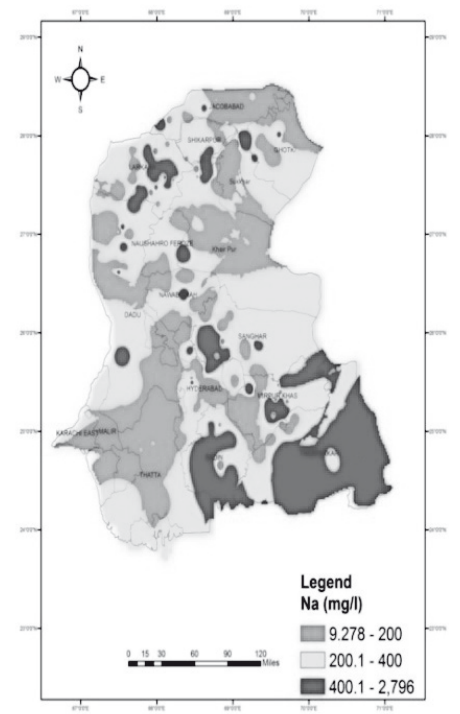

h)

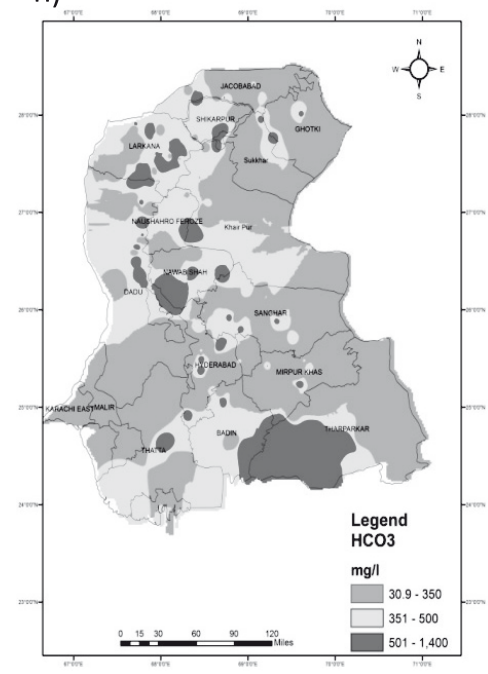

c)

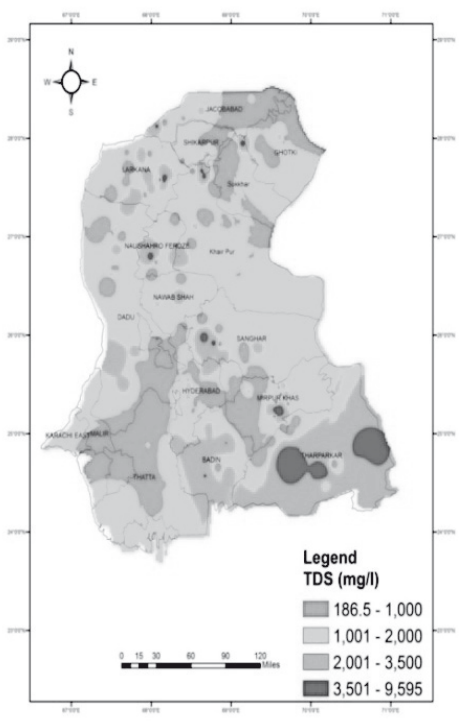

f)

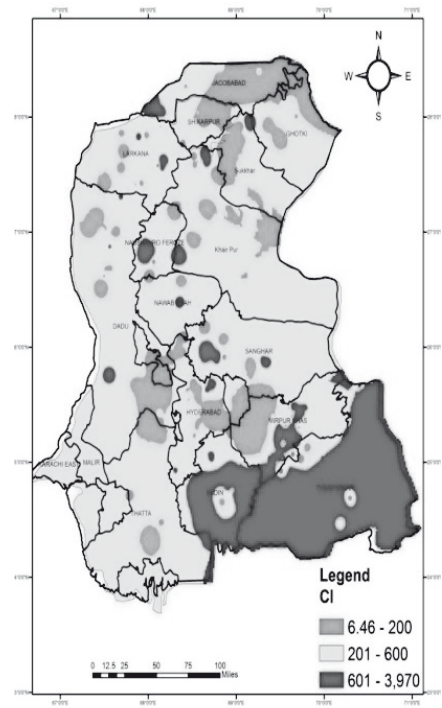

i)

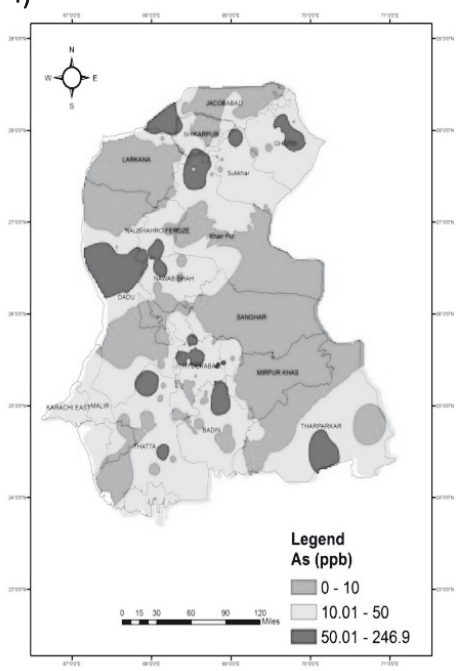

Fig. 3. Spatial distribution of major parameters, anions, cations, and Arsenic in Sindh groundwater. a) EC concentratio, b) $\mathrm{pH}$ concentration, c) TDS concentration, d) Hardness concentration, e) $\mathrm{Na}^{+}$concentration, f) $\mathrm{Cl}^{-}$concentration, g) Sulphate concentration, h) $\mathrm{HCO}_{3}^{-}$ concentration, i) Arsenic in ground water. 
Table 4. Classification of groundwater from drinking perspective (Arumugam et al. 2009: Davis and DeWiest 1966).

\begin{tabular}{|c|c|c|c|c|c|c|c|c|}
\hline EC & Water class & $\begin{array}{c}\text { Number of } \\
\text { samples+(\%) }\end{array}$ & TDS & Water class & $\begin{array}{c}\text { Number of } \\
\text { samples+ } \\
(\%)\end{array}$ & Hardness & $\begin{array}{c}\text { Water class } \\
\text { of samples } \\
+(\%)\end{array}$ \\
\hline 1500 & Permissible & $108(49.54 \%)$ & $<500$ & $\begin{array}{c}\text { Desirable for } \\
\text { drinking }\end{array}$ & $67(30.73 \%)$ & $<75$ & Soft & $1(0.45 \%)$ \\
\hline $1500-3000$ & $\begin{array}{c}\text { Not } \\
\text { permissible }\end{array}$ & $53(24.31 \%)$ & $500-1000$ & $\begin{array}{c}\text { Permissible } \\
\text { for drinking }\end{array}$ & $50(22.93 \%)$ & $75-150$ & $\begin{array}{c}\text { Moderately } \\
\text { soft }\end{array}$ & $37(16.9 \%)$ \\
\hline$>3000$ & Hazardous & $57(26.18 \%)$ & $1000-3000$ & $\begin{array}{c}\text { Useful for } \\
\text { irrigation }\end{array}$ & $76(34.86 \%)$ & $150-300$ & Hard & $55(25.2) \%$ \\
\hline Total & & $>3000$ & $\begin{array}{c}\text { Unfit for } \\
\text { drinking and } \\
\text { irrigation }\end{array}$ & $25(11.46 \%)$ & $>300$ & Very hard & 125 \\
$(57.3 \%)$
\end{tabular}

could also be a reason for arsenic dissociation. Also, bicarbonate elevation may result from microbial activities as well, which may lead to arsenic mobilization through competitive sorption under high $\mathrm{pH}$ [38]. A good positive correlation of $\mathrm{HCO}_{3}{ }^{-}$with $\mathrm{Ca}^{2+}(\mathrm{r}=0.76),\left(\mathrm{Mg}^{2+}=0.72\right)$, and $\mathrm{Na}^{+}(\mathrm{r}=0.66)$ reflects that the dissolution of silicate and carbonate minerals results in a substantial amount of $\mathrm{HCO}_{3}^{-}$by water-rock interaction [39]. PC3 explains a weak negative impact of $\mathrm{pH}$ on $\mathrm{NO}_{3}^{-}$, calcite, and dolomite dissolution as well. This factor further explains the major cation distribution resulting from mineral weathering and water-rock interaction.

\section{Hydrochemical Facies}

The relative proportion of major ions in water can be classified through hydrogeochemical facies [40]. Piper diagrams are the best graphical representation for the determination of water type and hydro chemical facies [41]. Groundwater is divided into six facies on the basis of

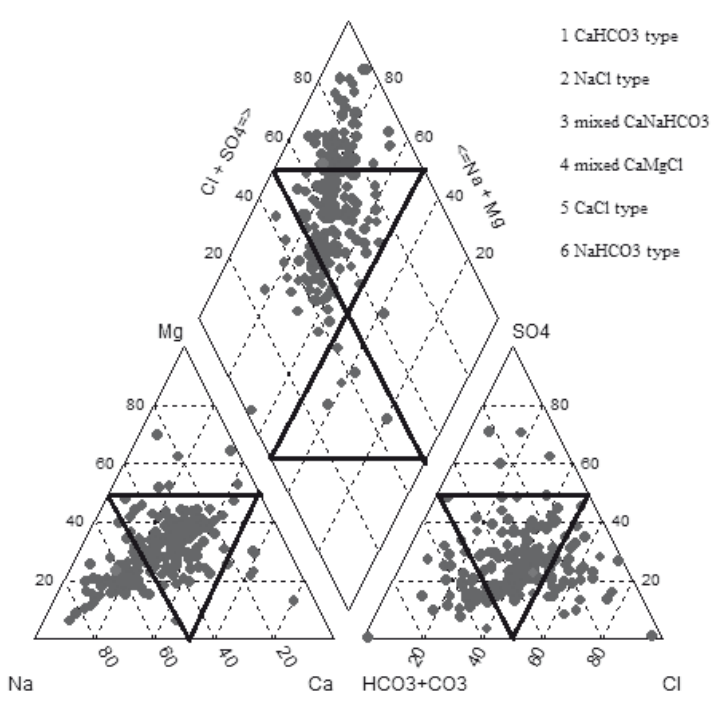

Fig. 4. Piper plot depicting hydrochemical facies of groundwater. chemical analysis (Fig. 4). The plot shows that the majority of the groundwater samples falls in the mix $\mathrm{CaMgCl}$, followed by $\mathrm{CaCl}, \mathrm{CaHCO}_{3}$, mixed $\mathrm{CaNaHCO}_{3}$, and a few in the $\mathrm{NaCl}$ plot, respectively. The cations plot shows that alkali $\mathrm{Na}^{+}$exceeds alkaline earths $\left(\mathrm{Mg}^{2+}\right.$ and $\left.\mathrm{Ca}^{+2}\right)$, while the majority of the samples were positioned in the mix plot to show the dominance of mixtures of $\mathrm{Ca}^{2+}, \mathrm{Mg}^{2+}$, and $\mathrm{Na}^{+}$. In the anions plot, $\mathrm{Cl}^{-}$and $\mathrm{HCO}_{3}{ }^{-}$were dominant over $\mathrm{SO}_{4}^{2-}$. This suggests that groundwater originates mainly from carbonate rock dissolution and is classified as $\mathrm{Na}-\mathrm{HCO}_{3}$ with high salinity, hence reflecting the saline nature of water. Some samples are pointed in the middle of the triangle showing the dominance of the mixture of anions.

\section{Water Quality Assessment for Drinking}

The analytical results of all the parameters are compared with Pakistan water quality standards and WHO [18] drinking water guideline (Table 1). Apart from six samples, all the $\mathrm{pH}$ samples are in the acceptable range. High EC was observed in the study area and $62.84 \%$ of samples exceeded the WHO standard of $1,000 \mu \mathrm{S} /$ $\mathrm{cm}$. Groundwater classification based on the electrical conductivity of Arumugam and Elangoyan [3] illustrates that $49.54 \%$ of samples are within permissible limits and $24.31 \%$ fall in the not permissible category, while $26.18 \%$ of samples were found to be hazardous (Table 4). TDS is important for water quality parameters and needs to be classified into classes to ascertain its suitability for various purposes [42]. $31 \%$ of the samples have TDS value less than $500 \mathrm{mg} / \mathrm{l}$ and were considered desirable for drinking, and $22.93 \%$ of the samples were found to be permissible for the drinking category. $34.86 \%$ samples were found useful for only irrigation, while $11.46 \%$ of the samples were considered unfit for irrigation as the TDS value exceeds 3,000 mg/L. Water with higher TDS makes it less palatable and can induce an unsuitable physiological reaction and may even result in gastrointestinal irritation [43]. Classification of groundwater based on hardness illustrates that the majority of the samples exceed the very hard water category of groundwater. Only a single 


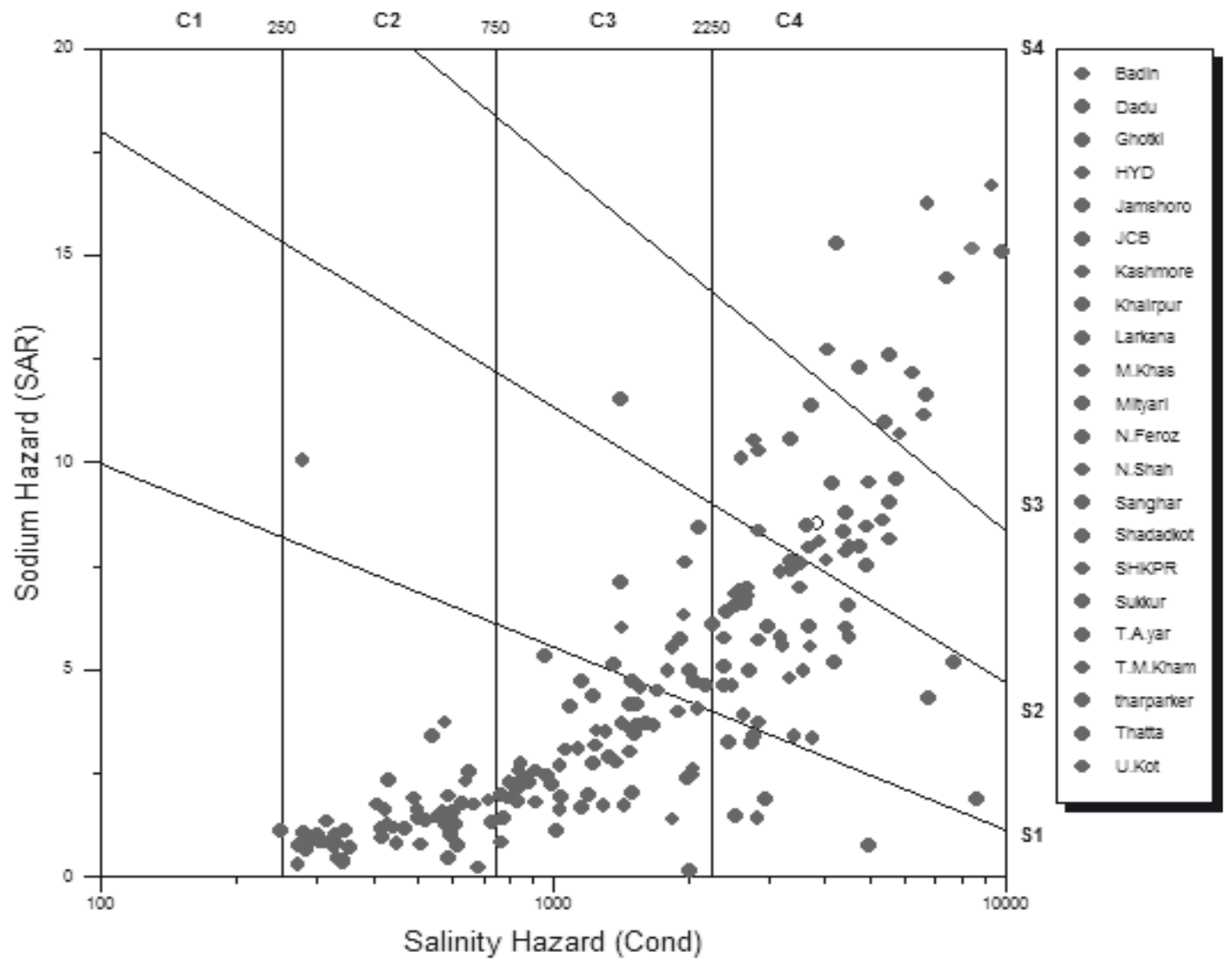

Fig. 5. Wilcox diagram showing classification of groundwater based on sodium hazard and salinity.

sample lies in the soft water category (75 mg/l) (Table 3), $16.9 \%$ were moderately soft, $25.2 \%$ were hard, and $57.3 \%$ were considered very hard. People are much more prone to gastrointestinal and dietary problems by utilizing this water.

In cations, $\mathrm{Na}^{+}$exceeds by $43 \%$ and $\mathrm{K}^{+} 8.2 \%$, while $\mathrm{Ca}^{2+}$ and $\mathrm{Mg}^{2+}$ exceed the WHO drinking water standards by $9.6 \%$. Among anions, $\mathrm{SO}_{4}^{2-}$ exceeds by $26.60 \%$ and can cause a laxative effect with human organs in the presence of magnesium Arumugam and Elangovan [3]. $\mathrm{HCO}_{3}^{-}$ exceeds $39.44 \%, \mathrm{Cl}^{-}$in $17.88 \%$, and $\mathrm{F}^{-}$exceeds $15.13 \%$ of samples, which can increase the chances of causing flourosis. $23.85 \%$ of samples were contaminated with high concentrations of arsenic, rendering the water unsuitable for drinking and leaving consumers vulnerable to many skin diseases and other health issues.

\section{Water Quality Assessment for Irrigation}

The suitability of water for irrigation depends on natural concentrations of soluble salts. High concentrations of salts in water creates problems like soil sodicity, salinity, and toxicity in surface layers and in the rhizospheric soil, which may inhibit plant growth [44]. The mineral constituents of water affect both soil and plants, and the extent of impact determines its suitability for irrigation. In this study, suitability of groundwater for irrigation was evaluated by the two basic parameters of EC and sodium absorption ratio (SAR). EC reflects salinity, while SAR is a measure of alkalinity hazard. High EC (excessive salinity of water) has been proven to be detrimental to crops by plummeting the osmotic activity of plants and thus interfering with the absorption of nutrients and water

Table 5. Suitability of groundwater for agriculture based on EC and SAR (Al-Khashman and Jaradat 2014).

\begin{tabular}{|c|c|c|c|c|c|c|}
\hline SAR & Alkalnity hazard & Water class & Number of samples $+(\%)$ & EC & Water class & Number of samples $+(\%)$ \\
\hline 10 & S1 & Excellent & $132(60.55)$ & $<250$ & Excellent & $1(0.46)$ \\
\hline $10-18$ & S2 & Good & $48(22.01)$ & $250-750$ & Good & $62(28.44)$ \\
\hline $18-26$ & S3 & Doubtful & $24(11)$ & $750-2250$ & Permissible & $71(32.56)$ \\
\hline$>26$ & S4 & Unsuitable & $14(6.4)$ & $\begin{array}{c}2250- \\
3000\end{array}$ & Doubtful & $27(12.38)$ \\
\hline & & & & $>3000$ & Unsuitable & $57(26.14)$ \\
\hline
\end{tabular}


from the soil [45]. The use of irrigation water having high SAR value can cause sodium accumulation in soil. A high SAR value implies that magnesium and calcium ions may be replaced in soil by sodium in the irrigation, potentially causing damage to the soil structure.

Groundwater has been classified into classes based on EC and SAR (alkalinity) (Table 5) [46]. Classification on EC shows that $28.44 \%$ of the samples were found to be good, 32.56 were permissible, $12.38 \%$ were doubtful, and $26.14 \%$ were unsuitable for irrigation. Mostly Tharparker (which is a desert region), Badin, and Thatta fall into this category where seawater intrusion takes place. Classification based on SAR shows that $60 \%$ of the samples were found to be an excellent category for irrigation and $22 \%$ were in a good category, while $11 \%$ and $6 \%$ were found to be doubtful and unsuitable, respectively.

A Wilcox diagram [47] can determine the suitability of groundwater for irrigation. In this diagram, SAR is taken as alkalinity hazard and EC is used as salinity hazard (Fig. 5). Salinity hazards are divided into points as 250 , 750 , and $2,250 \mu \mathrm{moh}$, resulting in four categories: low salinity water (C1), medium salinity water (C2), high salinity water (C3), and very high salinity water (C4). Low sodium water (S), medium sodium water (S2), high sodium water (S3), and very high sodium water (S4). Accordingly, $64.67 \%$ of groundwater samples are distributed in C2-S1 and $\mathrm{C} 3-\mathrm{S} 1$, indicating medium and high salinity and low sodium levels. Such water can be used for all soil types with little danger of $\mathrm{Na}^{+}$exchange. Six samples fall in the C4-S1 category having high salinity and low sodium level. This water type holds suitable for plants having high salt tolerance. Its use can be restricted in soils with no proper drainage.

In Sindh, rice wheat areas (Larkana, Jacobabad, Badin, Thatta, Sukkur, and parts of Dadu) have serious drainage problems due to slow permeable deep strata, the presence of extensive depressed areas, and clayey soil responsible for impeded drainage [48]. The use of this type of water cannot be recommended prior to proper drainage practices. $14.67 \%$ of samples fall in the C4-S2 plot indicating high salinity and medium alkalinity hazards. $10.55 \%$ of samples fall in the C4-S3 plot, while 16 samples were found in the C4-S4 plot - indicating high salinity and very high alkalinity hazards. These types of water are not recommended for irrigation purposes prior to extensive proper treatment and management practices.

It was observed that groundwater samples from lower southern Sindh Province (including Tharparker, Thatta, and Badin), exhibit higher concentrations of water quality parameters for irrigation than the permissible limit and hence discourage its use for irrigation purposes. Tharparker is a desert area where agricultural activities are negligible, while agricultural production in Thatta and Badin have been seriously compromised due to seawater intrusion. According to the International Irrigation Management Institute survery, an increasing trend in agricultural production - especially for wheat and cotton - was observed in upper Sindh, while a decreasing trend in yield was observed in lower Sindh - especially Thatta and Badin during 1947-95 [49]. The majority of farmers cited the high water table (44\%) and scarcity of appropriate irrigation water $(23 \%)$ as the main reason behind low wheat and cotton yields.

\section{Conclusion}

The Lower Indus Plain in the Sindh Province of Pakistan has prevailing ground water condition from neutral to slightly alkaline in nature. With respect to EC, the GW of the study area is not entirely fit for direct drinking as more than $50 \%$ of the samples were beyond the permissible drinking limit of EC while $34.86 \%$ of the samples exceed the WHO standard limit of TDS. Hard groundwater prevails in most of Sindh as $56.42 \%$ of ground water was under the very hard water category. Sulphate, bicarbonate, chlorine, calcium, magnesium, and sodium were the major contributors to groundwater salinity. The high water table, seawater intrusion, excessive use of fertilizer, and the geological settings of the area are the main factors behind water quality deterioration.

Arsenic is the most-distributed heavy metal in Sindh Province and a concentration of $250 \mathrm{ppb}$ was detected in some districts whose mobilization was believed to be positively affected by Fe. The hydrogeochemical facies indicates that alkali $\left(\mathrm{Na}^{+}\right)$exceeds alkaline earth metal levels $\left(\mathrm{Ca}^{2+}, \mathrm{Mg}^{2+}\right)$ and $\mathrm{Cl}^{-}$and $\mathrm{HCO}_{3}^{-}$exceed $\mathrm{SO}_{4}^{2-}$. This indicates saline groundwater and suggests carbonate weathering as the source of solutes within the groundwater of Sindh. Suitability of groundwater for drinking purposes based on EC classification indicates $49.54 \%$ of the GW permissible for drinking and $53.66 \%$ of samples were allowable for drinking based on TDS, while 57.3\% were found in the very hard category of groundwater. Based on SAR, $82.51 \%$ of GW was considered suitable for irrigation in almost all type of soils with a slight risk of $\mathrm{Na}$ exchange, and $26.14 \%$ of samples were found unsuitable for irrigation due to seawater intrusion, which restricts its direct use for agricultural purposes. This study recommends proper drainage practices to be adopted in the study area - especially in the irrigated area and the coastal regions to reduce salinity and protect the water table and monitor groundwater, whether the sources come from agricultural or industrial activities. Furthermore, we recommend proper management practices at lower Sindh to avoid seawater intrusion in the GW to avoid deterioration of groundwater quality.

\section{Acknowledgements}

The author would like to acknowledge the material support from PCRWR Pakistan and the China Scholarship Council for providing scholarship. We also like to appreciate the reviewers and editors for their suggestions and comments. 


\section{References}

1. AL-AHMADI M.E. Groundwater quality assessment in Wadi Fayd, Western Saudi Arabia. Arab J. Geosci. 6, 247, 2013.

2. NICKSON R.T., MCARTHUR J.M., SHRESTHA B., KYAW-MYINT T.O., LOWRY D. Arsenic and other drinking water quality issues, Muzaffargarh District. Pakistan. Appl. Geochem. 55, 2005.

3. ARUMUGAM K., ELANGOVAN K. Hydrochemical characteristics and groundwater quality assessment in Tirupur Region, Coimbatore District, Tamil Nadu, India. Environ. Geol. 58, 1509, 2009.

4. HELIOS-RYBICKA E., KNOCHEL A., MEYER A., PROTASOWICKI M., POPRAWSKI L., WOLSKAL., NAMIESNIK J. Distribution of pollutants in the Odra river system. Part I. General description of the International Odra Project (IOP). Pol. J. Environ. Stud. 11 (6), 649, 2002.

5. JIANMIN BIAN, CAIHONG LIU, ZHENZHEN ZHANG, RUI WANG, YUE GAO. Hydro-Geochemical Characteristics and Health Risk Evaluation of Nitrate in Groundwater. Pol. J. Environ. Stud. 25 (2), 521, 2016.

6. PCRWR (PAKISTAN COUNCIL OF RESERCH IN WATER RESOURCES). Water quality statistics in rural areas of Pakistan. Publication no: 143-2010, 2010.

7. HABIB Z. Water Management and Reservoirs in Pakistan, South Asian Journal, South Asian Free Media Association, available at: http://www.southasianmedia.net/Magazine/ Journal/ previousissues11.htm, 2008.

8. ALAMGIR A., KHAN M.A., SCHILLING J., SHAUKAT S.S., SHAHAB S. Assessment of groundwater quality in the coastal area of Sindh province, Pakistan. Environ. Monit. Assess, 188, 78, 2016

9. MAHMOOD K., ALAMGIR A., ALI KHAN A.M., SHOUKAT S.S., ANWAR M., SIKANDAR KHAN SHERWANI S. K. Seasonal variation in water quality of lower sindh, pakistan. FUUAST J. BIOL. 4 (2), 147, 2014.

10. MEMON M., SOOMRO M.S., AKHTAR M.S., MEMON K.S. Drinking water quality assessment in Southern Sindh (Pakistan). Environ. Monit. Assess. 177, 39, 2011.

11. MAJIDANO S.A., ARAIN G.M., BAJAJ D.R., IQBAL P., KHUHAWAR M.Y. Assessment of groundwater quality with focus on arsenic contents and consequences. Case study of Tando Allahyar District in Sindh Province. Int. J. Environ. Health Eng. 1, 91, 2010.

12. ALI B.M.A. Fifty years of environmental degradation. Pakistan Environment, Digest, 2, 91, 1997.

13. WCD (WORLD Commission on Dams). Tarbela Dam and related aspects of the Indus river basin in Pakistan, 2000.

14. SHAH S.M.I. Stratigraphy of Pakistan. Memoirs of the Geological Survey of Pakistan, 22, 240, 2009.

15. APHA. Standard methods for the examination of water and wastewater, 17th edn. APHA, Washington, DC, 1995.

16. WHO (World Health Organization). Guidelines for drinking water quality, recommendations, $2^{\text {nd }}$ edn. WHO, Geneva, 1 , 130, 1993.

17. ESRI. ArcGIS GeoStatistical Analyst Documentation. 2003.

18. WHO (WORLD HEALTH ORGANIZATION). Guidelines for THIRD EDITION Volume 1, 2004.

19. SINGLEY J.E., BEAYDET B.A., MARKEY P.H., DEBERRY D.W., KIDWELL J.R., MALISH D.A. Corrosion prevention and control in water treatment and supply system. Park Ridge: Noyes. 1985

20. SOHANI D., PANDE S., SRIVASTAV V. Ground water quality at Tribal Town: Nandurbar (Maharashtra). Indian J. Env. Ecoplan. 5 (2), 475, 2011.
21. KAZMI A.H., JAN. Q. Geology and Tectonics of Pakistan. Graphics Publisher, Karachi, 554, 2011.

22. BRITISH COLOMBIA (BC) Ground Water Association. Hardness in Ground Water. 2007.http://www.env.gov.bc.ca/ wsd/plan_protect_sustain/groundwater/library/ground_fact_ sheets/

23. SENGUPTA P. Potential Health Impacts of Hard Water. Int J Prev Med. 4 (8), 866, 2013.

24. STEENBERGEN F.V., BASHARAT M., LASHARI B.L. Key Challenges and Opportunities for Conjunctive Management of Surface and Groundwater in Mega-Irrigation Systems: Lower Indus, Pakistan. Resources, 4, 831, 2015.

25. PCRWR (Pakistan Council of Reserch in Water Resources). Water quality statistics in rural areas of Pakistan. Publication no: $143,2010$.

26. MAJIDANO S.A., ARAIN G.M., BAJAJ D.R., IQBAL P., KHUHAWAR M.Y. Assessment of groundwater quality with focus on arsenic contents and consequences. Case study of Tando Allahyar District in Sindh Province. Int. J. Environ. Health. Eng. 1, 91, 2010.

27. HUSAIN V., NASEEM S., KHANA., BHATTACHARYAP., ARAIN G.M. Natural arsenic in groundwater of Indus delta in the province of Sindh, Pakistan. In: Noller, B.N., Naidu, R., Bundschuh, J., Bhattacharya, P. (Eds.), Understanding the Geological and Medical Interference of Arsenic-Ng, Taylor \& Francis Group, London. 2012.

28. ARAIN G.M., ASLAM M., MAJIDANO S.A. Arsenic contamination of underground water in district matiari and Khairpur. J. Chem. Soci. Pak. 25 (5), 2007.

29. MEMON A.H., GHANGHRO A.B., JAHANGIR T.M., LUND G.M. Arsenic Contamination in Drinking Water of District Jamshoro, Sindh, Pakistan. Biomed Lett 2 (1), 31, 2016.

30. FAROOQI A., HARUE M. Toxic fluorides and arsenic contaminated groundwater in the Lahore and Kasur Districts, Punjab Pakistan and possible contaminants sources. Environ. Poll. 145 (3), 839, 2016.

31. PAKISTAN COUNCIL OF RESEACH IN WATER RESOURCES. Report on Technical Assessment of Water Supply Schemes, Sindh Province, Volume I. Publication No 150-2012. 2012.

32. ARAIN M.B., KAZI T.G., BAIG J.A., JAMALI M.K., AFRIDI H.I., SHAH A.Q., JALBANI N., SARFRAZ R.A. Determination of arsenic levels in lake water, sediment, and foodstuff from selected area of Sindh, Pakistan: Estimation of daily dietary intake. Food Chem Toxicol, 47 (1), 242, 2009.

33. ABBAS Z., SU C., TAHIRA F., WILSON H., MAPOMA T., AZIZ Z.A. Quality and hydrochemistry of groundwater used for drinking in Lahore, Pakistan: analysis of source and distributed groundwater. Environ. Earth. Sci. 74, 4281, 2015.

34. HELENA R., PARDO M., VEGA E., BARRADO J.M., FERNANDEZ L. Temporal evolution of groundwater composition in an alluvial aquifer (Pisuerga river, Spain) by principal component analysis. Water Res. 34 (3), 807, 2000.

35. AHMED K.M., BHATTACHARYA P., HASAN M.A., AKHTER S.H., ALAM S.M.M., BHUYIAN M.A.H., IMAM M.B., KHAN A.A., SRACEK O. Arsenic enrichment in groundwater of the alluvial aquifers in Bangladesh: An overview. App. Geochem. 19, 181, 2004.

36. KIM M.J., NRIAGU J., HAACK S. Carbonate ions and arsenic dissolution by groundwater. Environ. Sci. Technol. 34, 3094, 2000.

37. ANWAR H.M., AKAI J., SAKUGAWA H. Mobilization of arsenic from subsurface sediments by effect of bicarbonate ions in groundwater. Chemosphere 54, 753, 2004. 
38. XIE X., WANG Y., SU C. Hydrochemical and sediment biomarker evidence of the impact of organic matter biodegradation on arsenic mobilization in shallow aquifers of Datong basin, China. Water Air Soil Poll. 223, 483, 2012.

39. JEEVANANDAM M., KANNAN R., SRINIVASALU S., RAMMOHAN V. Hydrogeochemistry and groundwater quality assessment of lower part of the ponnaiyar river basin, Cuddalore District, South India. Environ. monit. assess. 132 (1-3), 263, 2007.

40. KEHEW A.E. Applied Chemical Hydrogeology. ISBN13: 978-0132709279. 2001.

41. PIPER A.M. A Graphical Procedure in the Geochemical Interpretation of Water Analysis. Am. Geophys Union Trans. 25, 914, 1944.

42. DAVIS S.N., DEWIEST R.J. Hydrogeology. Wiley, NewYork. 1966.

43. ADAK M.G., PUROHIT K.M. Chemical Properties of Drinking Water of Some Villages in Sangamner Tahasil, Dist- Ahmednagar, Maharashtra, India and its Impact on Human Health, Poll. Res. 20, 575, 2001.

44. NICOLÁS E., ALARCÓN J. J., MOUNZER O., PEDRERO F., NORTES P. A., ALCOBENDAS ROMERO-
TRIGUEROS C., BAYONA J. M., MAESTRE-VALERO

J. F. Long-term physiological and agronomic responses of mandarin trees to irrigation with saline reclaimed water. Agricul. Water Mgt. 166, 1, 2016.

45. SUBRAMANI T., ELANGO L., DAMODARASAMY S.R. Groundwater quality and its suitability for drinking and agricultural use Chithar River Basin, Tamil Nadu, India. Environ. Geol. 47, 1099, 2005.

46. KASHMAN O.A., JARADAT A.Q. Assessment of groundwater quality and its suitability for drinking and agricultural uses in arid environment. Stoch. Environ. Res. Risk. Assess. 28, 743, 2014.

47. WILCOX L.V. Classification and use of irrigation waters. US Dept Agric Circ 19. US Department of Agriculture, Washington, DC, 969, 1955.

48. ASLAM M., PRATHAPAR S.A. Strategies to mitigate secondary salinization in the Indus Basin of Pakistan: A selective review. Research Report 97. Colombo: International Water Management Institute (IWMI), 2006.

49. JAHANGIR W.A., ALI M. Water logging and Salinity Management in the Sindh Province Pakistan. International Irrigation Managemnet Institute. 1998. 